\title{
Association between Numerical Variations of Vertebrae and Carcass Traits in Jeju Native Black Pigs, Landrace Pigs, and Crossbred $F_{2}$ Population
}

In-Cheol Cho', Sang-Keum Kim', Yoo-Kyung Kim', Yong-Jun Kang', Sung-Nyun Yang', Yong-Sang Park', Won-Mo Cho', Sang-Rae Cho', Nam-Young Kim', Hyun-Seok Chae', Pil-Nam Seong ${ }^{2}$, Beom-Young Park $^{2}$, Lee Jun-Heon ${ }^{3}$, Jae-Bong Lee, Chae-Kyoung Yoo ${ }^{4}$, Sang-Hyun Han ${ }^{5}$ and Moon-Suck Ko ${ }^{1} \star$

\author{
${ }^{1}$ Subtropical Animal Experiment Station, National Institute of Animal Science, Joiu 690-150, Korea \\ ${ }^{2}$ Animal Products Research and Development Division, National Institute of Animal Science, Suwon 441-706, Korea \\ ${ }^{3}$ Department of Animal Science and Biotechnology, Chungnam National University, Daejeon 305-764, Korea \\ ${ }^{4}$ Division of Applied Life Science, Gyeongsang National University, Jinju 660-701, Korea \\ ${ }^{5}$ Educational Science Research Institute, Jeju National University, Jeju 690-756, Korea
}

Received April 10, 2013 /Revised July 9, 2013 /Accepted July 14, 2013

\begin{abstract}
The number of thoracic and lumbar vertebrae is known to be an unfixed trait among mammals. This study focused on the relationship between numerical variations of cervical (CER), thoracic (THO), and lumbar (LUM) vertebrae and the total number of vertebrae (TNV) and carcass traits in Jejunative black pigs (JBPs), Landrace pigs, and their intercrossed $F_{2}$ population. There were no numerical variations in CER vertebrae. On the other hand, the numbers of THO and LUM vertebrae and the TNV varied in all three populations. Of the traits investigated in the three populations, only the means $\pm \mathrm{SE}$ of the LUM vertebrae did not show statistical significance $(p>0.05)$. The carcass weights $(\mathrm{CW})$, meat color (MC), marbling score (MS), backfat thickness (BFT), carcass length (CLE), THO vertebrae, and TNV all showed statistical significance $(p<0.05)$. The JBP had 14 - 16 THO vertebrae, 5 - 6 LUM vertebrae, and 27 - 29 TNV. The Landrace pigs had 15-16 THO vertebrae, 5-7 LUM vertebrae, and $28-29$ TNV. The $\mathrm{F}_{2}$ population had 14-17 THO vertebrae, 5-7 LUM vertebrae, and $27-30 \mathrm{TNV}$. In the $\mathrm{F}_{2}$ population, increased numbers of THO vertebrae and TNV were associated with a significant increase in the CW, CLE, and BFT $(\not<0.05)$. In particular, the increase in the TNV was caused by an increase in the number of THO rather than LUM vertebrae. Although the animals with a greater number of THO and TNV had thicker backfat, they had a longer CLE and a heavier CW. Both these traits are economically more important than the level of backfat when determining the productivity level. These results suggest that genetic selection to increase the number of vertebrae, especially in Landrace pigs, JBPs, and their related populations, may be an excellent strategy for improving productivity.
\end{abstract}

Key words : Numerical variation, vertebrae, carcass traits, Jeju Native Black pig, Landrace

\section{서 론}

포유류에서 척추(vertebrae) 수열은 발생학적인 제한을 받 는다. 나무늘보(sloth)나 manatee 무리를 제외한 거의 모든 포 유류에서 심지어 기린이나 고래까지도 경추(cervical)의 수는 7개로 고정되어 있고, 흥추(thoracic)와 요추(lumbar)의 합은 보통 19 개를 나타내지만, 종에 따른 변이를 보인다. 예를 들 어, 단공류(Monotremata), 유대류(Marsupialia), 토끼목

\footnotetext{
*Corresponding author

Tel : +82-64-754-5714, Fax : +82-64-743-5713,

E-mail : hansh04@naver.com and

Tel : +82-64-754-5701 Fax : +82-64-743-5713,

E-mail : koms21c@korea.kr

This is an Open-Access article distributed under the terms of the Creative Commons Attribution Non-Commercial License (http://creativecommons.org/licenses/by-nc/3.0) which permits unrestricted non-commercial use, distribution, and reproduction in any medium, provided the original work is properly cited.
}

(Lagomorpha), 설치목(Rodentia), 우제목(Artiodactyla)에서 흥추-요추 수는 대부분 19 개, 기제목(Perissodactyla; 말, 24 개)과 식육목(Carnivora; 개, 20 개)에서는 증가된 양상을, 유인 원목(Primata)에서는 17 개로 감소된 양상을 보인다. 하지만 이 러한 변화는 진화적 과정을 통해 형성된 것으로 보이며, 각각의 종 내에서 혈통이나 집단에 따른 변이를 나타내는 경우는 선택 적인 압력(selective press)에 의한 것으로 추정되고 있다[26, 28].

오랜 기간을 통해 양돈업에서는 돈육의 생산량 증가와 번식 관련 형질의 개선을 위해 체장에 대한 선발육종을 진행해왔 다. 그 결과로 서구의 상업돈 품종에서 흥추-요추 수가 22-23 개로 증가된 것으로 추정되고 있다. 가축돼지의 원형이라고 할 수 있는 야생멧돼지와 다수의 재래종에서 흥추-요추 수는 각각 변이가 있더라도 그 합은 19-20 개를 나타내며 $[2,3,20$, 24,26 , 상업돈에서는 흥추 수 12-17 개, 요추 수 5-7 개로 흥추요추 수는 19-23 개의 범위에까지 이르는 것으로 보고되었다 $[2,3,12-13,20-21,24]$. 일반적으로 돼지의 척추 수는 체장과 
높은 연관을 보이는 것으로 알려져 있으며, 등심의 길이는 등 심단면적, 등지방두께와 부의 상관관계를 갖는 것으로 보고되 었다 $[1,10,29]$. 돼지의 척추 수는 높은 수준의 유전력을 나타 내고[2], 척추 수가 증가함에 따라 도체중, 도체장, 유두 수 등 이 함께 증가한다고 보고되었다[20, 29]. 분자유전학의 연구를 통해 척추 수와 관련된 양적형질좌위(quantitative trait loci, QTL)가 돼지 염색체(Sus scrofa chromosome, SSC) 1번, 2번과 7번, 13번, 14번, 16 번 염색체 등에서 보고되었다. SSC1의 경우 Göttingen miniature pig와 Meishan 품종의 교배를 통해 보고 되었으나, 유럽 상업 품종에서는 발견되지 않았고[35], 이후의 연구들을 통해 Duroc, Landrace 등을 비롯한 여러 돼지 품종 에서 척추 수 관련 QTL이 SSC7에서 보고되었다 $[6,23,25,32$, 34]. 현재까지 돼지의 척추 수 변이의 원인 유전자로는 SSC7의 vertnin (VRTM)이 강력한 QTL 후보로 알려져 있으나[11, 23-25], 척추 수의 변이와 상관된 SSC7 이외의 다른 염색체 영역을 감안한다면 $V R T N$ 유전자의 독립적인 효과가 아닌 또 다른 유전자들과의 상호작용에 의한 결과라는 가설도 제안되 었다[29].

최근 형성되고 있는 고가의 흑돼지시장의 활성화를 위한 유 전적인 개량이 요구되고 있다. 제주재래흑돼지는 예로부터 크 기가 작고, 통통한 체형에 전신 흑모색을 나타내는 특징이 있다. 1990년대 들어 멸종에서의 보호를 위해 제주특별자치도 축산 진흥원에서 원형에 가까운 흑돼지 축군을 수집하여 현재까지 보호되고 있으나, 소비자의 흑돼지 선호와 더불어 산업화를 위 한 요구가 지속적으로 접수되고 있는 실정이다 $[5,7,14-15,27]$. 이에 반해 현재까지의 제주재래흑돼지에 대한 유전적인 개량 을 위한 시도는 순종수준의 육성에만 초점이 맞추어져 있을 뿐, 품종 간 교잡에 의한 명확한 품종의 특성 구명과 비교연구도 거의 없다. 근래에 제주재래흑돼지와 Landrace의 $\mathrm{F}_{2}$ 교배집단 에 대한 분자유전학적 특성 구명을 위한 연구결과들이 진행되 어 후보유전자 수준의 상관관계 분석[6-8]과 경제형질관련 관 련 QTL 연구결과[22, 36-37] 등이 보고되기 시작하였다.

본 연구에서는 현재까지 우리나라에서 양돈업에 이용되고 있는 서구에서 수입된 상업 품종이나 재래종인 제주재래흑돼 지의 척추 수의 유전적 변이에 대한 보고뿐만 아니라 유전적 변이에 의한 도체의 특성 변화에 대한 연구는 전혀 없는 실정 에서, 제주재래흑돼지와 우리나라에서 비육돈 생산에 많이 활 용되는 Landrace 품종의 교배에서 생산된 $\mathrm{F}_{2}$ 교배집단에 대한 척추 수의 다형성과 도체형질의 상관관계를 구명하여 제주재 래흑돼지 관련 축군을 이용한 교배체계 및 유전적 개량을 위 한 기초자료를 마련하고자 수행하였다.

\section{재료 및 방법}

\section{공시동물}

본 연구에 이용된 제주재래흑돼지와 Landrace 품종 간의
$\mathrm{F}_{2}$ 후손집단은 농촌진흥청 국립축산과학원 난지축산시험장에 서 생산한 동물들을 이용하였다. 부모 세대인 제주재래흑돼지 와 Landrace 순종 집단에서 각각 선정된 종빈돈과 종모돈을 이용하여 $\mathrm{F}_{1}$ 세대를 생산하고, 생산된 $\mathrm{F}_{1}$ 에서 부모세대 품종의 성별과 역방향으로 번식돈을 선발하여 상호교차 방식으로 교 배하여 $\mathrm{F}_{2}$ 집단을 2 차에 걸쳐 생산하였다. 공식동물의 생산과 관리는 Cho 등의 보고[4]에 구체적으로 기술되어 있다. 공시 동물의 생산에 이용된 제주재래흑돼지와 Landrace 품종 부모 세대에 대한 척추 수 다형성과 도체형질 조사를 위해 선발된 개체들과 동복인 개체들(제주재래흑돼지 21 두, Landrace 43 두)과 $F_{2}$ (1,079 두)를 도축하여 측정하였다. 제주재래흑돼지는 생후 280 일, Landrace는 180 일, $\mathrm{F}_{2}$ 는 190 일에 각각 도축하여 척추 수의 측정과 도체형질에 대한 성적 조사하였다.

\section{측정형질}

도축을 마친 후, 급냉과정을 거친 반도체 상태나 $1^{\circ} \mathrm{C}, 24$ 시간 경과 후 경추 수(number of cervical vertebrae, CER), 흥추(number of thoracic vertebrae, $\mathrm{THO}$ ), 요추(number of lumbar vertebrae, LUM), 전체 척추 수(total number of vertebrae, $\mathrm{TVN}=\mathrm{CER}+\mathrm{THO}+\mathrm{LUM}$ )와 도체장 (carcass length, $\mathrm{CLE}$ ) 을 측정하였다. 흉추 수는 갈비뼈의 수를 측정한 자료를 이용 하고, 척추 수의 측정과정에서 기형이나 부분적인 유합, 만곡 등 비정상적인 형태를 보이는 개체는 통계분석에서 제외하였 으며, 도체장은 목(어깨 위)-둔부까지의 길이를 직접 측정하였 다. 도체형질은 도축 24 시간 후 냉도체를 대상으로 축산물등 급판정세부기준에 따라 축산물품질평가원 소속 축산물품질 평가원이 측정하였다. 측정한 도체형질은 도체중(carcass weight, $\mathrm{CW}$ ), 등지방두께(backfat thickness, BFT), 등심단면 적(eye muscle area, EMA), 근내지방도(marbling score, MS), 육색(meat color, $\mathrm{MC}$ ) 등으로 축산물등급판정확인서의 기록 으로 구분하였다.

\section{척추 수의 변이와 도체형질의 유의성분석}

제주재래흑돼지와 Landrace, 교잡종인 $\mathrm{F}_{2}$ 집단에서 측정한 도체형질과 척추 수 등에 대한 연관분석을 수행하였다. 전체 에서 수적인 차이를 나타내지 않은 $\mathrm{CER}$ 은 통계분석에서 제외 하였다(Table 2). 각각의 도체중, 도체장 및 도체형질에 대한 흥추, 요추, 전체 척추 수의 다형성에 대한 유의성 분석은 SAS [30]의 GLM procedure로 분석하였으며, 형질의 평균간 유의 성 검정 $(p<0.05, p<0.01, p<0.001)$ 은 Duncan의 다중검정방법 (multiple range test)으로 차이를 각각 비교하였다.

\section{결과 및 고찰}

제주재래흑돼지를 이용한 산업화와 유전적 형질 개량을 위 하여 제주재래흑돼지와 Landrace 품종의 교배집단과 순종 집 
단에서 도체형질, 척추 관련 형질(CER, THO, LUM, TVN)의 다형성과 이들 간의 상관관계를 분석하였다.

\section{제주재래흑돼지, Landrace와 교배 $F_{2}$ 집단의 도체형질}

제주재래흑돼지, Landrace, 두 품종의 상호교배집단인 $\mathrm{F}_{2}$ 에 서 측정한 도체형질에 대한 유의성 분석을 수행한 결과, 조사 한 모든 형질 중에서 경추 수와 요추 수를 제외한 모든 형질들 이 고도의 유의적인 차이를 나타내었다( $\beta \times 0.05$, Table 1). 도체 중에서 제주재래흑돼지는 $72.90 \pm 1.27 \mathrm{~kg}$ 으로 Landrace 품종 $(86.49 \pm 0.95 \mathrm{~kg})$ 에 비해 평균 $13.5 \mathrm{~kg}$ 정도 가벼웠고, 도체장도 $9.8 \mathrm{~cm}$ 정도 짧은 것으로 조사되었다. $\mathrm{F}_{2}$ 의 경우 도체중과 도체 장 모두 제주재래흑돼지와 Landrace의 중간 정도의 수준을 나타내었다(도체중 $79.43 \pm 1.40 \mathrm{~kg}$, 도체장 $102.72 \pm 0.57 \mathrm{~cm}$ ). 등 심단면적은 Landrace가 제주재래흑돼지보다 $3.89 \mathrm{~cm}^{2}$ 만큼 더 넓었으며, 등지방두께는 제주재래흑돼지 $(37.10 \pm 0.92 \mathrm{~mm})$ 가 Landrace $(34.06 \pm 1.32 \mathrm{~mm})$ 에 비해 더 두꺼운 것으로 확인 되었다. 반면, 육질의 척도인 근내지방도는 제주재래흑돼지가 $3.30 \pm 0.69$, Landrace가 $1.81 \pm 0.61$ 로, 제주재래흑돼지의 근내지 방도가 Landrace보다 약 1.5 이상 높은 수준을 보였다.

Kim 등 [19]은 제주재래돼지의 도체형질에 대한 연구보고 에서 210 일령에 출하된 제주재래돼지의 도체중은 $72.94 \mathrm{~kg}$, 근내지방도는 3.61 정도인 것으로 보고하였다. 한편, 경북의 재래돼지는 240 일 $75 \mathrm{~kg}$ 출하 기준으로 도체중 $52.8 \mathrm{~kg}$, 배최 장근 조지방 함량 $3.05 \%$ 정도이고[15], 강원도의 재래돼지는 180 일 생체중이 평균 $64 \mathrm{~kg}$, 배최장근 조지방 함량은 $4.13 \%$ 정도의 성적을 나타내었다[17]. 한편 국립축산과학원에서 복 원사업 중인 재래돼지의 경우 192 일 출하체중이 평균 $72 \mathrm{~kg}$ 내외인 것으로 보고되었다[5]. 본 연구에서 조사된 제주재래돼 지의 경우 도체중은 280 일 출하 기준으로 평균 $72.90 \mathrm{~kg}$ 의 수준을 나타내었고, 180 일 출하된 Landrace는 $86.49 \mathrm{~kg}, 190$ 일에 출하된 $\mathrm{F}_{2}$ 교배집단은 평균 $79.43 \mathrm{~kg}$ 의 수준을 나타내었 다. 전체적으로 제주재래흑돼지가 Landrace에 비해 $85 \%$ 정도 의 수준이나, 사육기간이 60 일 정도 더 길다는 점에서 Landrace 도체중에 대한 비율이 실제 $70 \%$ 이하로 기록된 연구
보고들[18, 27]과 거의 유사한 결과라 하겠다.

배최장근 육색은 제주재래흑돼지에서 4.60으로 Landrace (3.56)에 비해 1.00 이상의 높은 수준을 나타내었다. 이는 육색 에 대한 재래돼지와 타 품종과의 비교 연구의 결과들[11, 13-15, 23]과 유사한 결과로, 세부적으로는 육색 중 적색도나 황색도, 또는 두 가지 모두가 타 품종에 비해 더 높은 것으로 보고되었다.

제주재래흑돼지와 Landrace, $\mathrm{F}_{2}$ 교배집단의 근내지방도에 대한 평가에서 제주재래흑돼지의 근내지방도는 3.30 정도로 매우 높은 수준을 나타내었고, Landrace와 $\mathrm{F}_{2}$ 교배집단에서는 $\mathrm{F}_{2}$ 가 다소 높기는 하나 큰 차이를 나타내지는 않았다. Kim 등[19]은 제주재래돼지의 도체형질 연구에서 근내지방도가 3.36 정도의 수준을 나타낸다고 보고하여, 본 연구의 제주재래 흑돼지의 연구결과와 비슷한 경향을 보였다. 뿐만 아니라, 제 주재래흑돼지 이외의 한반도 재래돼지 집단과 Landrace, 일반 상업돈에 대한 비교연구들도 경상북도와 강원도, 국립축산과 학원의 재래돼지 모두 근내지방도는 Landrace나 일반 상업돈 에 비해 우수한 것으로 보고하고 있다[15, 17-18].

Table 2는 제주재래흑돼지와 Landrace, 이들 사이에서 생산 된 $\mathrm{F}_{2}$ 교배집단의 도체성적을 암-수 성별에 따라 비교한 것이 다. 도체형질 조사에서 제주재래흑돼지의 수컷은 암컷에 비해 체중은 대략 $5 \mathrm{~kg}$ 이상 더 무겁고, 도체장은 $4 \mathrm{~mm}$ 정도 더 길고, 등심단면적이 더 넓으며, 등지방두께는 더 얇은 수준을 나타내었다. Landrace의 경우 암컷과 수컷의 도체형질에서 눈 에 띄는 뚜렷한 차이는 발견되지 않았으나, 암컷보다 수컷의 근내지방도의 수준이 더 높은 것으로 조사되었고, 육색은 암 컷이 더 진한 양상을 보였다. $\mathrm{F}_{2}$ 교배집단에서는 수컷의 육색 수준이 암컷보다 0.3 이상 더 높은 수준을 보이고, 근내지방도 의 수준은 암컷이 더 높았다.

제주재래흑돼지와 Landrace, 교배 $F_{2}$ 집단에서 흉추, 요 추, 척추 수의 다형성

Table 3 은 제주재래흑돼지와 Landrace, 이들 사이의 $\mathrm{F}_{2}$ 교 배집단에서 조사된 흥추, 요추, 전체 척추(경추+흥추+요추) 수

Table 1. Mean and SE of carcass traits and vertebral numbers in JBP, Landrace, and their $\mathrm{F}_{2}$ population

\begin{tabular}{lrcccc}
\hline Trait $^{1}$ & JBP $(\mathrm{n}=21)$ & Landrace $(\mathrm{n}=43)$ & $\mathrm{F}_{2}(\mathrm{n}=1,079)$ & $p$ value & Significance $^{2}$ \\
\hline CW & $72.90 \pm 1.27$ & $86.49 \pm 0.95$ & $79.43 \pm 1.40$ & $5.30 \times 10^{-5}$ & $* * *$ \\
MC & $4.60 \pm 0.33$ & $3.56 \pm 0.39$ & $4.02 \pm 0.37$ & $4.51 \times 10^{-5}$ & $* * *$ \\
MS & $3.30 \pm 0.69$ & $1.81 \pm 0.61$ & $1.89 \pm 0.86$ & $1.82 \times 10^{-5}$ & $* * *$ \\
EMA & $17.48 \pm 0.56$ & $28.26 \pm 0.83$ & $21.39 \pm 0.89$ & $1.33 \times 10^{-32}$ & $* * *$ \\
BFT & $37.10 \pm 0.92$ & $26.09 \pm 1.01$ & $34.06 \pm 1.32$ & $2.26 \times 10^{-11}$ & $* * *$ \\
CLE & $97.81 \pm 0.62$ & $107.02 \pm 0.33$ & $102.72 \pm 0.57$ & $3.23 \times 10^{-9}$ & $* *$ \\
THO & $14.71 \pm 0.19$ & $15.63 \pm 0.12$ & $15.24 \pm 0.16$ & $3.64 \times 10^{-7}$ & $* * *$ \\
LUM & $5.90 \pm 0.12$ & $6.00 \pm 0.13$ & $6.03 \pm 0.16$ & 0.314 & n.d. \\
TNV & $27.62 \pm 0.11$ & $28.63 \pm 0.09$ & $28.27 \pm 0.12$ & $1.31 \times 10^{-8}$ & $* * *$ \\
\hline
\end{tabular}

${ }^{1}$ All abbreviations for each trait are given in the section Materials and Methods.

${ }^{2}$ Significance of ${ }^{* * *}$ and indicates $p$-value $<0.001$, and n.d. indicates not detected. 
Table 2. Mean and SD of carcass traits and vertebral numbers according to genders in JBP, Landrace, and their $\mathrm{F}_{2}$ population

\begin{tabular}{lccrrrr}
\hline \multirow{2}{*}{ Trait $^{1}$} & \multicolumn{3}{c}{ JBP } & \multicolumn{2}{c}{ Landrace } & $\mathrm{F}_{2}$ \\
\cline { 2 - 7 } & Female $(\mathrm{n}=10)$ & \multicolumn{1}{c}{ Male $(\mathrm{n}=11)$} & Female $(\mathrm{n}=20)$ & Male $(\mathrm{n}=23)$ & Female $(\mathrm{n}=521)$ & Male $(\mathrm{n}=558)$ \\
\hline CW & $70.40 \pm 9.25$ & $75.18 \pm 12.04$ & $86.15 \pm 8.36$ & $86.78 \pm 9.66$ & $79.29 \pm 11.80$ & $79.55 \pm 4.22$ \\
MC & $4.67 \pm 0.71$ & $4.27 \pm 0.47$ & $3.70 \pm 0.66$ & $3.38 \pm 0.81$ & $3.88 \pm 0.70$ & $4.22 \pm 0.75$ \\
MS & $3.33 \pm 1.32$ & $3.27 \pm 1.10$ & $1.70 \pm 0.80$ & $1.94 \pm 0.85$ & $2.17 \pm 1.37$ & $1.51 \pm 0.74$ \\
EMA & $16.90 \pm 2.13$ & $18.00 \pm 2.49$ & $29.20 \pm 4.15$ & $27.43 \pm 4.64$ & $21.23 \pm 3.86$ & $21.53 \pm 4.32$ \\
BFT & $38.90 \pm 4.18$ & $35.45 \pm 6.41$ & $25.75 \pm 3.48$ & $26.39 \pm 6.49$ & $35.10 \pm 7.31$ & $33.09 \pm 7.89$ \\
CLE & $95.60 \pm 6.65$ & $99.62 \pm 5.06$ & $107.20 \pm 3.22$ & $106.87 \pm 3.56$ & $102.45 \pm 5.60$ & $102.98 \pm 5.93$ \\
THO & $14.50 \pm 0.71$ & $14.91 \pm 0.70$ & $15.75 \pm 0.44$ & $15.52 \pm 0.51$ & $15.22 \pm 0.64$ & $15.27 \pm 0.64$ \\
LUM & $5.90 \pm 0.32$ & $5.91 \pm 0.30$ & $6.05 \pm 0.22$ & $5.96 \pm 0.38$ & $6.05 \pm 0.39$ & $6.01 \pm 0.39$ \\
TNV & $27.40 \pm 0.52$ & $27.82 \pm 0.60$ & $28.80 \pm 0.41$ & $28.48 \pm 0.51$ & $28.27 \pm 0.62$ & $28.27 \pm 0.64$ \\
\hline
\end{tabular}

${ }^{1}$ All abbreviations for each trait are given in the section Materials and Methods.

에 대한 자료이다. 양친 품종과 $\mathrm{F}_{2}$ 교배집단에서 다형성이 발 견되지 않은 경추 수(CER)는 제시하지 않았다. 흥추 수는 갈비 뼈 수를 세어 환산하였다. 제주재래흑돼지 품종에서는 흥추 수는 적게는 14 개에서 많은 것은 16 개까지 출현하였으며, 14 개인 경우가 가장 많았고(47.6\%), 16 개인 개체의 빈도가 가장 적었다(14.3\%). 반면 Landrace의 경우 흥추 수가 14 개인 개체는 발견되지 않았고, 16 개인 개체들이 가장 높은 빈도 (62.8\%)를 나타내어, 두 품종의 흥추 수는 상이한 양상을 나타 내었다. 척추 수의 경우 제주재래흑돼지 품종과 Landrace에서 각각 27-29 개, 28-29 개로 확인되었다. $\mathrm{F}_{2}$ 교배집단의 척추 수는 27-30 개로 조사되었고, 28 개인 경우가 전체의 $56.3 \%$ 로 가장 많은 분포를 보였다(Table 3).

현재까지 제주재래흑돼지뿐만 아니라 우리나라에 도입되 어 사육되고 있는 유럽원산의 상업돈 품종에 대한 척추 수와 관련된 연구는 보고되지 않고 있다. 기존 보고들에서 아시아 재래돼지들과 야생멧돼지에서 흥추-요추 수가 대부분 19 개, 유럽의 개량돼지 품종들에서 20 개 이상인 경우에 비해 1-2 개 적은 양상을 보이고, 대표적인 유럽 품종인 Landrace와 Duroc, Yorkshire, Berkshire, Pietrain 등에서 흥추 수는 13-16 개, 요추 수는 5-7 개를 나타내며, 전체 척추 수 또는 흥추-요추 수 역시 아시아 재래돼지 품종들에 비해 1 개 이상 많은 양상 임이 보고되었다[2, 3, 12-13, 20-21, 23, 25].

제주재래흑돼지에서 나타난 흥추 수는 $14.71 \pm 0.19$ 개로 Landrace의 $15.63 \pm 0.12$ 개에 비해 대략 1 개 정도 적은 것은 아시아형 재래돼지의 특성이 야생형과 가깝다는 Mikawa 등
의 가설 $[23,25]$ 과 유사한 결과라 하겠다. 반면, Table 3에 제 시된 것과 같이 전체 $14.3 \%$ 의 제주재래흑돼지에서 출현하는 흥추 수 16 개인 개체들은 과거 제주도에 유입된 Berkshire, Hampshire 뿐만 아니라, Duroc, Landrace, Large White 등의 유럽 품종들의 도입과 교잡을 통한 개량이 진행되었다는 점 에서 유럽 개량돼지 품종의 증진된 유전자형이 그 당시 제주 재래흑돼지 품종 내로 유입된 결과로 추정된다. 또한 $\mathrm{F}_{2}$ 집단 에서 출현하는 흥추 수 17 개(1.6\%), 전체 척추 수가 30 개 $(1.1 \%)$ 인 형질은 부모세대인 제주재래흑돼지와 Landrace 집 단에서는 발견되지 않았다. 이는 도축성적을 확보하기 위해 이용한 제주재래흑돼지와 Landrace 돼지들은 교배집단을 만 드는 데 이용되지 않았고, 동복의 형매를 도축하여 얻은 결과 이기 때문에 실제 제주재래흑돼지와 Landrace 품종에서 흥 추, 전체 척추 수의 다형성의 변이폭은 본 연구결과보다 더 넓을 것으로 추정된다. 다시 말해 제주래재흑돼지이건, Landrace이건 흥추 수 또는 척추 수가 더 많은 개체들의 존재 가능성을 시사하며, 이를 증명하기 위해서는 두 순종 집단에 서 더 많은 개체들을 대상으로 한 조사가 필요하다고 하겠다. 기존의 보고에서 Landrace 품종은 흥추 수 12-16 개 13-15 개 또는 14-17 개, 흥추+요추 수는 21-23 개로 보고되어, 흥추 수 의 폭이 적게는 12 개에서 많게는 17 개까지 분포한다고 보고 되었다[2, 12-13, 21]. 중국의 재래돼지품종인 Meishan, Taoyuan 등은 13-17 개의 흥추+요추 수를 나타내는 것으로 보고되었다[2, 3].

종 내에서 척추 수의 수적인 변이가 진화적 관점에서 선택

Table 3. Numbers and frequencies of THO, LUM and TNV in JBP, Landrace, and their $\mathrm{F}_{2}$ population

\begin{tabular}{|c|c|c|c|c|c|c|c|c|c|c|c|}
\hline \multirow{2}{*}{ Breed } & \multicolumn{4}{|c|}{ THO } & \multicolumn{3}{|c|}{ LUM } & \multicolumn{4}{|c|}{ TNV } \\
\hline & 14 & 15 & 16 & 17 & 5 & 6 & 7 & 27 & 28 & 29 & 30 \\
\hline \multirow{2}{*}{$\mathrm{JBP}(\mathrm{n}=21)$} & 10 & 8 & 3 & 0 & 2 & 19 & 0 & 9 & 11 & 1 & 0 \\
\hline & 0.476 & 0.381 & 0.143 & 0.000 & 0.095 & 0.905 & 0.000 & 0.429 & 0.524 & 0.048 & 0.000 \\
\hline \multirow{2}{*}{ Landrace $(n=43)$} & 0 & 16 & 27 & 0 & 2 & 39 & 2 & 0 & 16 & 27 & 0 \\
\hline & 0.000 & 0.372 & 0.628 & 0.000 & 0.047 & 0.907 & 0.047 & 0.000 & 0.372 & 0.628 & 0.000 \\
\hline \multirow{2}{*}{$\mathrm{F}_{2}(\mathrm{n}=1,079)$} & 105 & 623 & 334 & 17 & 67 & 914 & 98 & 95 & 607 & 365 & 12 \\
\hline & 0.097 & 0.577 & 0.310 & 0.016 & 0.062 & 0.847 & 0.091 & 0.088 & 0.563 & 0.338 & 0.011 \\
\hline
\end{tabular}


적인 압력에 의해 결정되는 형질이며, 선택의 효과는 집단이 나 혈통에 따라 달라질 수 있음을 제안하고 있다[2, 20, 29]. 또한 척추의 수와 관련한 형질이 부모에게서 물려받은 대립인 자형에 완전히 고정되는 질적형질(qualitative trait)이 아닌 양 적으로 연속적인 변이를 갖는 양적형질(quantitative trait)이 라는 점이다. 즉, 흥추 수 14 또는 16 개인 경우는 동형접합, 15 개는 이형접합에 의해 결정되는 대립유전자형의 효과가 아니라, 여러 가지 유전자의 상호작용에 의해 결정되는 형질 이라는 것이다. 기존 연구에서 척추 수의 일반적인 유전력 $h^{2}=0.62$ 로 조사된 바[2] 역시 척추 수의 유전형상이 양적유전 형질임을 뒷받침해주는 자료라 하겠다. Mikawa 등[25]이 제 안한 척추 수에 대한 후보유전자 $V R T N$ 의 야생형 $(\omega t)$ 과 변이 형 $(Q, q)$ 을 나타내고 있으나, 우열의 관계나 염기서열의 변이 에 의해 완전히 고정된 형질을 발현하지는 않는 양적형질로 보고하였다. 연구진에 의한 사전조사에서는 일반 양돈농가에 서 출하된 비육돈의 경추 수, 흥추 수, 요추 수, 척추 수는 각각 7 개, 14-19 개, 5-8 개, 26-31 개의 범위에서 관찰되어(data not shown), 본 연구에서 조사된 제주재래흑돼지, Landrace, $\mathrm{F}_{2}$ 교배집단 등의 성적보다 훨씬 더 폭넓은 분포를 보였다. 이는 농가의 비육돈들이 다양한 품종을 이용한 여러 가지 형태의 교배를 통해 만들어진 축군임을 감안하면, 여러 품종의 유전 적 배경이 다양한 표현형의 변이를 만들어낸 것으로 추측되었 다. 또한 수가 고정되어 있는 경추를 제외한 흥추, 요추, 전체 척추 수는 둘 또는 그 이상의 유전자의 영향을 복합적으로 받는다고 가정할 수 있다. 향후 품종별 분포 및 변이의 범위와 여러 가지 교배에서 출현하는 변이의 범주를 확인하여 자료화 한다면, 척추 수와 관련한 비육돈의 체형개선을 위한 육종전 략 마련에 도움을 줄 수 있을 것으로 기대된다.

\section{$F_{2}$ 집단의 흉추, 요추 수, 척추 수의 다형성과 도체형질의} 상관관계

Table 4 는 제주재래흑돼지와 Landrace 사이의 교잡 $\mathrm{F}_{2}$ 교배 집단에서 흥추 수에 따른 도체형질의 평균값에 대한 유의성의 분석한 것이다. 흥추 수는 14 개에서 17 개까지 출현하였다. 등지방두께는 흥추 수가 많아질수록 두꺼워지는 양상을 나타
내었다( $p \times 0.05)$. 도체중과 도체장은 흥추 수가 많은 개체가 적 은 개체에 비해 도체중은 무거워지고, 도체장의 길이는 증가 하였고, 평균 값 사이에는 고도의 유의차를 나타내었다 $(p<0.001)$. 도체중은 흥추 수 14 개 $(76.99 \pm 1.42 \mathrm{~kg})$ 에 비해 15 개 $(78.82 \pm 1.39 \mathrm{~kg})$ 와 16 개 $(81.13 \pm 1.39 \mathrm{~kg})$ 에서 약 $1.8 \mathrm{~kg}$, 4.1 $\mathrm{kg}$ 더 무거워지는 것으로 확인되어, 흥추 수 1 개가 증가함에 따라 $1.8 \mathrm{~kg}$ 이상 도체중이 증가하는 것으로 관찰되었다. 도체 장은 흥추 수 14 개 $(101.63 \pm 0.64 \mathrm{~cm}), 15$ 개 $(102.39 \pm 0.58 \mathrm{~cm})$, 16 개 $(103.56 \pm 0.53 \mathrm{~cm})$ 로 흥추 수 1 개 증가에 따라 $0.9 \mathrm{~cm}$ 정도 더 길어지는 결과를 확인할 수 있었다. 도체형질 중 육색, 근내지방도, 등 심단면적의 크기 등은 유의적인 차이를 나타내 지 않았다(p>0.05). 돼지의 척추 수는 높은 수준의 유전력을 나타내고[2], 척추 수가 1 개 증가할 때, 도체중, 도체장, 유두 수가 증가한다고 보고되어 있어[1, 10, 20, 29], 본 연구결과 역시 기존의 보고와 동일한 양상을 나타내었다.

$\mathrm{F}_{2}$ 교배집단에서 요추 수와 도체형질의 상관관계 분석결과 는 Table 5에 나타내었다. 요추 수는 $F_{2}$ 교배집단에서 5 개부터 7 개까지 출현하였으나, 요추 수를 기준으로 한 도체형질의 성적에서는 조사된 모든 항목에서 평균값의 유의차는 발견되 지 않았다( $p>0.05)$. 도체장의 경우 요추 수가 증가함에 따라 도체장도 증가하는 양상을 나타내었으나, 평균값의 유의차는 발견되지 않았다( $p>0.05)$.

\section{$\mathrm{F}_{2}$ 집단의 전체 척추 수의 다형성과 도체형질의 상관관계}

$\mathrm{F}_{2}$ 교배집단의 척추 수는 적게는 27 개부터 많게는 30 개까 지 변이를 보였다(Table 6). 척추 수에 따른 도체형질의 유의성 을 분석할 결과에서는 전체 척추 수가 증가함에 따라 등지방 두께가 증가하는 양상이 유의적인 것으로 나타났으나 $(p<0.05)$, 척추 수가 29 개인 개체군의 평균이 30 개인 개체군 의 평균에 비해 더 두꺼운 양상을 나타내었다. 이는 척추 수가 30 개인 축군의 크기가 작아 $(\mathrm{n}=12)$ 직접적인 비교에 부적절한 것으로 추정되나, 향후 시료의 추가 확보 등을 통해 추가연구 가 필요하다고 하겠다. 도체형질 중 도체중과 도체장의 경우 척추 수에 따른 평균의 차이가 고도의 유의성을 나타내는 것 으로 확인되었다( $p<0.001)$. 도체중은 척추 수의 증가에 따라

Table 4. Mean and SE of carcass traits according to THO in $\mathrm{JBP} \times$ Landrace $\mathrm{F}_{2}$ population

\begin{tabular}{|c|c|c|c|c|c|c|}
\hline \multirow{2}{*}{ Trait $^{1}$} & \multicolumn{4}{|c|}{ Number of thoracic vertebrae (THO) } & \multirow{2}{*}{$p$ value } & \multirow{2}{*}{ Significance $^{2}$} \\
\hline & $14(n=105)$ & $15(n=621)$ & $16(n=334)$ & $17(n=17)$ & & \\
\hline $\mathrm{CW}$ & $76.99 \pm 1.42$ & $78.82 \pm 1.39$ & $81.13 \pm 1.39$ & $82.12 \pm 1.15$ & 0.00042 & ** \\
\hline MC & $3.95 \pm 0.41$ & $4.00 \pm 0.37$ & $4.08 \pm 0.35$ & $4.13 \pm 0.25$ & 0.723 & n.d. \\
\hline MS & $1.70 \pm 0.71$ & $1.86 \pm 0.69$ & $2.01 \pm 1.12$ & $2.00 \pm 0.85$ & 0.671 & n.d. \\
\hline EMA & $21.52 \pm 0.84$ & $21.47 \pm 0.94$ & $21.20 \pm 0.79$ & $20.76 \pm 0.92$ & 0.563 & n.d. \\
\hline BFT & $32.19 \pm 1.28$ & $33.70 \pm 1.30$ & $35.10 \pm 1.32$ & $38.18 \pm 1.50$ & 0.009 & * \\
\hline CLE & $101.63 \pm 0.64$ & $102.39 \pm 0.58$ & $103.56 \pm 0.53$ & $104.35 \pm 0.36$ & $2.02 \times 10^{-5}$ & $* * *$ \\
\hline
\end{tabular}

${ }_{1}^{1}$ All abbreviations for each trait are given in the section Materials and Methods.

${ }^{2}$ Significances of $*, * *$ and ${ }^{* * *}$ indicate $p$-value $<0.05,<0.01$ and $<0.001$, respectively, and n.d. indicates not detected. 
Table 5. Mean and SE of carcass traits according to LUM in JBP $\times$ Landrace $\mathrm{F}_{2}$ population

\begin{tabular}{lrrrrr}
\hline \multirow{2}{*}{ Trait $^{1}$} & \multicolumn{3}{c}{ Number of lumbar vertebrae (LUM) } & \multirow{2}{*}{ vvalue $^{*}$ Significance $^{2}$} \\
\cline { 2 - 4 } CW & $5(\mathrm{n}=67)$ & $6(\mathrm{n}=914)$ & $80.10 \pm 1.35$ & 0.720 & n.d. \\
MC & $78.96 \pm 1.35$ & $79.39 \pm 1.41$ & $4.10 \pm 0.36$ & 0.342 & n.d. \\
MS & $3.88 \pm 0.34$ & $4.02 \pm 0.37$ & $1.80 \pm 0.69$ & 0.621 & n.d. \\
EMA & $1.76 \pm 0.81$ & $1.91 \pm 0.89$ & $21.81 \pm 0.84$ & 0.399 & n.d. \\
BFT & $21.28 \pm 0.75$ & $21.35 \pm 0.90$ & $33.52 \pm 1.21$ & 0.796 & n.d. \\
CLE & $34.00 \pm 1.45$ & $34.12 \pm 1.32$ & $103.87 \pm 0.65$ & 0.075 & n.d. \\
\hline
\end{tabular}

${ }^{1}$ All abbreviations for each trait are given in the section Materials and Methods.

${ }^{2}$ n.d. indicates not detected.

Table 6. Mean and SE of carcass traits according to TNV in JBP $\times$ Landrace $\mathrm{F}_{2}$ population

\begin{tabular}{|c|c|c|c|c|c|c|}
\hline \multirow{2}{*}{ Trait $^{1}$} & \multicolumn{4}{|c|}{ Total number of vertebrae (TNV) } & \multirow{2}{*}{$p$ value } & \multirow{2}{*}{ Significance } \\
\hline & $27(n=95)$ & $28(\mathrm{n}=607)$ & $29(n=365)$ & $30(n=12)$ & & \\
\hline $\mathrm{CW}$ & $76.59 \pm 1.34$ & $78.67 \pm 1.42$ & $81.38 \pm 1.36$ & $80.75 \pm 1.23$ & $2.40 \times 10^{-5}$ & $* * *$ \\
\hline $\mathrm{MC}$ & $3.87 \pm 0.39$ & $3.99 \pm 0.38$ & $4.10 \pm 0.35$ & $4.18 \pm 0.20$ & 0.267 & n.d. \\
\hline MS & $1.67 \pm 0.74$ & $1.85 \pm 0.69$ & $2.01 \pm 1.08$ & $1.73 \pm 0.69$ & 0.703 & n.d. \\
\hline EMA & $21.27 \pm 0.81$ & $21.50 \pm 0.94$ & $21.23 \pm 0.81$ & $21.25 \pm 0.98$ & 0.299 & n.d. \\
\hline BFT & $32.82 \pm 1.27$ & $33.43 \pm 1.33$ & $35.39 \pm 1.27$ & $35.17 \pm 1.60$ & 0.019 & * \\
\hline CLE & $100.98 \pm 0.57$ & $102.31 \pm 0.58$ & $103.82 \pm 0.54$ & $104.17 \pm 0.45$ & $5.44 \times 10^{-9}$ & $* * *$ \\
\hline
\end{tabular}

${ }^{1}$ All abbreviations for each trait are given in the section Materials and Methods.

${ }^{2}$ Significances of * and ${ }^{* * *}$ indicate $p$-value $<0.05$ and $<0.001$, respectively, and n.d. indicates not detected.

대략 평균 $2.0 \mathrm{~kg}$ 정도씩 증가하였으나, 척추 수가 29 개인 축군의 평균은 30 개인 축군의 평균보다 더 높은 경향을 보였 다. 도체장의 경우 척추 수의 증가는 크게는 $1.5 \mathrm{~cm}$ 부터 적게 는 $0.35 \mathrm{~cm}$ 가량 더 길어지는 양상을 나타내었다. 도체중과 도체장의 평균 비교에서 나타난 매우 높은 수준의 유의성을 감안하면, 추후 척추 수의 증가를 통해 제주재래흑돼지나 Landrace 품종을 이용하는 육종체계에 적용하는 것이 산육량 의 증가에 따른 경제적인 효과를 창출하는 좋은 모델이 될 것으로 판단된다.

\section{흉추 수, 요추 수와 전체 척추 수의 상관관계}

제주재래흑돼지와 Landrace 사이에서 생산된 교배 $\mathrm{F}_{2}$ 집단 에서 척추 수와 흥추, 요추 수의 상관관계를 알아보기 위하여 통계적인 유의성 분석을 수행하였다. 그 결과 척추 수의 증가 는 흥추 수, 요추 수에 대해 각각 고도의 상관을 나타내었고 $(p<0.001)$, 둘 중에서 요추 수보다 흥추 수와 더 밀접한 정의 상관이 있음을 나타내었다(Table 7). 다시 말해 흥추 수의 증가 가 요추 수의 증가보다 척추 수를 증가시키는 데 훨씬 더 기여 하고 있다고 하겠다. 이로 인해 제주재래흑돼지와 Landrace와 관련된 교배축군의 육성에 있어 산육량의 증가를 위해서, 요 추 수보다는 흥추 수의 증가에 따른 체형의 신장이 더 효과적 인 육종방법이 될 것으로 판단된다.

척추 수 관련 분자유전학 연구와 산업적 활용

돼지의 체형에 관한 연구 중에서 척추 수는 일반적으로 높
은 유전력 $\left(h^{2}=0.62\right)$ 을 나타내며[2], 척추 수 1 개당 $15 \mathrm{~mm}$ 정도 의 도체장이 증가될 것으로 예측되었다[20]. Ren 등[29]의 보 고와 Borchers 등[2]의 보고에서는 척추 수의 변이가 도체중과 도체장, 240 일령 체중과 유두 수 등의 표현형과 연관되어 있 다고 기술하였고, King과 Roberts [20]는 도체장에서의 변이가 흥추와 요추 수의 변이에 기인한다고 보고하였다. 또한 본 연 구결과에서는 척추 수의 증가가 요추 수의 증가보다는 흥추 수의 증가에 의해 더 많은 영향을 받는다는 점이 발견되었다. 이는 척추 수 또는 흥추 수의 증가를 통해 돼지의 체형 개선뿐 만 아니라 경제성을 향상시킬 수 있는 중요한 척도가 될 수 있음을 시사하는 자료라 하겠다.

Hirose 등[11]은 척추 수의 두 번째 연관 유전자로 보고한 SSC7의 VRTN 유전자형의 분포에 따른 Duroc 품종의 핵군에 대한 육종 형질에 대한 연관성 분석에서 아시아 재래돼지 품 종에서 빈번하게 발견되는 유전자형인 야생형 $(\omega t)$ 유전자형 을 보유한 축군이 척추 수를 증가와 정의 상관을 보이는 유럽 상업돼지 품종의 주 유전자형인 $Q$ 유전자형을 보유한 축군에 서 근내지방도, 근내지방도 육종가, 도체장, 체고 등과 상관관 계가 있음을 제시하였다. 이 보고가 비록 척추 수의 변이를 기준으로 한 도체형질의 통계치를 비교한 자료는 아니지만, 현재까지 알려진 유전자 중에서는 돼지의 척추 수를 결정하는 가장 강한 연관을 나타내는 유전자의 대립인자형을 근거로 하고 있다는 점에서 무시할 수 없는 결과라 하겠다. 돼지의 척추 수 관련 QTL이 SSC7 VRTN또는 인근 위치에 존재한다 는 보고는 다양한 돼지품종들에서 확인되었고 $[6,11,23,25$, 
Table 7. Mean and SE of THO and LUM according to TNV in JBP $\times$ Landrace $\mathrm{F}_{2}$ population

\begin{tabular}{|c|c|c|c|c|c|c|}
\hline \multirow{2}{*}{ Trait $^{1}$} & \multicolumn{4}{|c|}{ Total number of vertebrae (TNV) } & \multirow{2}{*}{$p$ value } & \multirow{2}{*}{ Significance } \\
\hline & $27(n=95)$ & $28(n=607)$ & $29(n=365)$ & $30(n=12)$ & & \\
\hline THO & $14.27 \pm 0.12$ & $15.00 \pm 0.09$ & $15.85 \pm 0.10$ & $16.83 \pm 0.09$ & $2.88 \times 10^{-274}$ & *** \\
\hline LUM & $5.73 \pm 0.19$ & $6.00 \pm 0.14$ & $6.15 \pm 0.16$ & $6.17 \pm 0.16$ & $9.58 \times 10^{-21}$ & $* * *$ \\
\hline
\end{tabular}

${ }^{1}$ All abbreviations for each trait are given in the section Materials and Methods.

${ }^{2}$ Significance of $* * *$ indicates $p$-value $<0.001$

29, 34], 흥추 수의 QTL이 SSC16에서 보고되기도 하였다[32]. 돼지 척추 수와 관련한 $\mathrm{SSC} 1$ 의 NR6A1은 유럽 상업 돼지품종 에서는 다형성이 확인되지 않았으나, 아시아 재래돼지 품종이 나 야생 멧돼지에서는 다형성이 알려져 있으며, 유전자형이 척추 수의 변이를 설명할 수 있는 것으로 제안되었다 $[6,24$, 29, 31, 35]. VRTN 유전자가 현재까지는 강력한 척추 수 관련 QTL 후보로 알려져 있기는 하지만, 여러 염색체에서 척추 수 와 관련한 QTL 영역들이 발견됨에 따라, 척추 수의 변이에 대한 원인 유전자는 $V R T N$ 이외의 다른 유전자들이 더 작용하 고 있을 것으로 제안되기도 하였다[29].

돼지의 체형과 관련한 분자유전학적 자료들은 다양한 품종 에서 보고되었으나, 척추 수에 관한 형질만 놓고 보더라도 아 직까지도 명확한 분자 수준의 조절을 설명할 수 있는 자료가 마련되지 않은 실정이며, 특히 우리나라 고유 품종인 제주재 래흑돼지나 한반도의 재래돼지 품종의 산업적 활용을 극대화 하기 위해서는 유전특성 구명과 함께 해당 형질의 원인 유전 자와 염기서열 상의 변이를 탐색하는 것이 선결과제라 하겠 다. 뿐만 아니라 우리나라에서 사용되고 있는 종돈 품종에 대 한 종축의 조기선발과 계획적인 관리를 위한 분자-도움선발 체계의 구축을 위한 분자수준의 연구가 요구되는 실정이다.

이상의 결과들을 종합해보면, 흥추 수와 척추 수의 증가는 제주재래흑돼지와 Landrace $\mathrm{F}_{2}$ 교배집단에서 도체중, 도체장 의 증가를 유도할 수 있는 좋은 육종전략이 될 수 있음을 보여 주고 있으나, 이와 더불어 등지방두께도 함께 증가한다는 점 도 간과해서는 안 됨을 나타내고 있다. 본 연구 결과는 국내에 서는 최초로 흥추, 요추, 척추 수의 다형성을 근간으로 도체형 질과의 연관을 분석한 기초자료로써, 현재까지 양돈업에서 단 순히 육량의 개선을 위해 체형이 긴 돼지품종을 이용하면 된 다는 식의 경험적인 육종체계의 제안이 아니라, 척추 수 내지 는 흥추 수가 많은 유전자형을 보유한 품종의 활용에 따른 체형의 개선이 궁극적으로 육량의 개선을 위한 더 좋은 육종 체계임을 제안할 수 있는 과학적이고 논리적인 자료가 될 것 으로 판단된다. 이와 더불어 SSC1과 SSC7의 QTL 등 기존의 연구보고에서 제시된 척추 수를 결정하는 후보 유전자군에 대한 유전자형의 분포와 도체형질과의 연관성, 제주재래흑돼 지의 $\mathrm{F}_{2}$ 교배집단에서 척추 수 관련형질에 대한 양적형질좌위 연구 자료가 보완된다면, 집단의 개량을 위한 유전자 마커-도 움 선발을 통한 분자육종의 체계를 구축하는 것도 가능할 것
으로 판단된다.

\section{감사의 글}

본 연구는 농촌진흥청 본청공동연구 “참조축군 유래 자손의 육질형 축군 조성"(과제번호. PJ90703502)의 지원에 의해 이루 어진 것임.

\section{References}

1. Bereskin, B. and Steele, N. C. 1988. Estimates of genetic parameters for carcass measures of body composition and growth in swine. J Anim Sci 66, 2498-2507.

2. Borchers, N., Reinsch, N. and Kalm, E. 2004. The number of ribs and vertebrae in a Pietrain cross: variation, heritability and effects on performance traits. I Anim Breed Genet 121, 392-403.

3. Chang, H. L., Wu, M. C., Wu, S. C., Liu, C. T. and Lai, Y. Y. 1998. Numbers of ribs in pigs. Proc $6^{\text {th }}$ WCGALP (Armidale) 23, 603-606.

4. Cho, I. C., Park, H. B., Yoo, C. K., Lee, G. J., Lim, H. T., Lee J, B., Jung, E. J., Ko, M. S., Lee, J. H. and Jeon, J. T. 2011. QTL analysis of white blood cell, platelet and red blood cell-related traits in an $\mathrm{F}_{2}$ intercross between Landrace and Korean native pigs. Anim Genet 42, 621-626.

5. Cho, S. H., Seong, P. N., Kim, J. H., Park, B. Y., Kwon, O. S., Hah, K. H., Kim, D. H. and Ahn, C. N. 2007. Comparison of meat quality, nutritional, and sensory properities of Korean Native pigs by gender. Korean J Food Sci Ani Resour 27, 475-481.

6. Edwards, D. B., Ernst, C. W., Raney, N. E., Doumit, M. E., Hoge, M. D. and Bates, R. O. 2008. Quantitative trait locus mapping in an $\mathrm{F}_{2}$ Duroc $\times$ Pietrain resource population: II. Carcass and meat quality traits. J Anim Sci 86, 254-266.

7. Han, S. H., Shin, K. Y., Lee, S. S., Ko, M. S., Jeong, D. K., Oh, H. S., Yang, B. C. and Cho, I. C. 2010. SINE indel polymorphism of $A G L$ gene and association with growth and carcass traits in Landrace $X$ Jeju Black pig F2 population. Mol Biol Rep 37, 467-471.

8. Han, S. H., Shin, K. Y., Lee, S. S., Ko, M. S., Oh, H. S. and Cho, I. C. 2012. Porcine SPP1 gene polymorphism association with phenotypic traits in the Landrace $\times$ Jeju (Korea) Black pig $\mathrm{F}_{2}$ population. Mol Biol Rep 39, 7705-7709.

9. Han, S. H., Shin, K. Y., Lee, S. S., Ko, M. S., Jeong, D. K., Jeon, J. T. and Cho, I. C. 2008. Effects of ADCYP1R1, FABP3, 
FABP4, MC4R, MYL2 genotypes on growth traits in $\mathrm{F}_{2}$ population between Landrace and Jeju Native Black pig. I Anim Sci Technol 50, 621-632.

10. Hicks, C., Satoh, M., Ishi, K., Kuroki, S. and Fujiwara, T. 1998. Estimates of genetic parameter for daily gain and carcass traits in swine. Anim Sci Technol 69, 1094-1098.

11. Hirose, K., Mikawa, S., Okumura, N., Noguchi, G., Fukawa, K., Kanaya, N., Mikawa, A., Arakawa, A., Ito, T., Hayashi, Y., Tachibana, F. and Awata, T. 2013. Association of swine vertnin (VRTM) gene with production traits in Duroc pigs improved using a closed nucleus breeding system. Anim $S C i$ $J$ 84, 213-221.

12. Hofmann, F. and Ritter, E. 1960. Untersuchungen über die röntgenologische Riooenzählung beim Schwein. Arch Tierz 3, 465-490.

13. Hugenroth, B. 1933. Aufbau und Leistungen der Erbstämme in der Schweinezucht des Münsterlandes. Thesis, Bonn, Germany.

14. Jin, S. K., Kim, C. W., Song, Y. M., Jang, W. H., Kim, Y. B., Yeo, J. S., Kim, J. W. and Kang, K. H. 2001a. Physicochemical characteristics of Longissimus muscle between the Korean Native pig and Landrace. Korean J Food Sci Ani Resour 21, 142-148.

15. Jin, S. K., Kim, C. W., Song, Y. M., Kwon, E. J., Hwang, S. S., Jang, W. H., Park, Y. A., Cho, K. K. and Lee, J. I. 2001b. Comparison of sensory evaluation, fatty acid and amino acid composition of Longissimus muscle between the Korean Native pig and Landrace. Korean J Food Sci Ani Resour 21, 183-191.

16. Jin, S. K., Kim I. S., Hur, S. J., Hah, K. H. and Kim, B. W. 2005. Physico-chemical characteristics with market weight in Korean Native and Landrace crossbred pigs. Korean J IntI Agri 17, 182-187.

17. Kang, S. M. and Lee, S. K. 2007. Quality comparison of $M$. lomgissimus from crossbred wild boars, Korean Native Black pigs and modern genotype pigs during refrigerated storage. J Anim Sci Technol 49, 257-268.

18. Kang, S. M., Kang, C. G. and Lee, S. K. 2007. Comparison of quality characteristics of Korean black pork and modern genotype pork dufing refrigerated storage after thawing. Korean J Food Sci Ani Resour 27, 1-7.

19. Kim, G. W., Yoo, J. Y., Kim, J. W., Kim, Y. B., Min, K. H. and Kim, S. E. 2010. Analysis of carcass characteristics by gender and carcass grades of Jeju native pigs. J Anim SCi Technol 52, 313-318.

20. King, J. W. B. and Roberts, R. C. 1960. Carcass length in the bacon pig: its association with vertebrae numbers and prediction from radiographs of the young pig. Anim Prod 2, 59-65.

21. Lindfeld, K. A. 1969. Untersuchengen über Wirbelzahl und Wirbelllänge beim deutschen veredelten Landschwein. Thesis, Hannover, Germany.

22. Maharani, D., Park, H. B., Lee, J. B., Yoo, C. K., Lim, H. T., Han, S. H., Lee, S. S., Ko, M. S., Cho, I. C. and Lee, J. H. 2013. Association of the encoding steroyl-CoA desaturase $(S C D)$ with fatty acid composition in an intercross pop- ulation between Landrace and Korean native pigs. $\mathrm{Mol}$ Biol Rep 40, 73-80.

23. Mikawa, S., Hayashi, T., Nii, M., Shimanuki, S., Morozumi, T. and Awata, T. 2005. Two quantitative trait loci on Sus scrofa-chromosomes 1 and 7 affecting the number of vertebrae. I Anim Sci 83, 2247-2254.

24. Mikawa, S., Morozumi, T., Shimanuki, S., Hayashi, T., Uenishi, H., Domukai, M., Okumura, N. and Awata, T. 2007. Fine mapping of a swine quantitative trait locus for number of vertebrae and analysis of an orphan nuclear receptor, germ cell nuclear factor (NR6A1). Genome Res 17, 586-593.

25. Mikawa, S., Sato, S., Nii, M., Morozumi, T., Yoshioka, G., Imaeda, N., Yamaguchi, T., Hayashi, T. and Awata, T. 2011. Identification of a second gene associated with variation in vertebral number in domestic pigs. BMC Genet 12, 5.

26. Narita, Y. and Kuratani, S. 2005. Evolution of the vertebral formulae in mammals: a perspective on developmental constraints. J Exp Zool 304, 91-106.

27. Park, J. C., Kim, Y. H., Jung, H. J., Park, B. Y., Lee, J. I. and Moon, H. K. 2005. Comparison of meat quality and physicochemical characteristics of pork between Korean Native Black pigs (KNBP) and Landrace by market weight. J Anim Sci Technol 47, 91-98.

28. Pilbeam, D. 2004. The anthropoid postcranial axial skeleton: comments on development, variation, and evolution. J Exp Zool 302, 241-267.

29. Ren, D. R., Ren, J., Ruan, G. F., Guo, Y. M., Wu, L. H., Yang, G. C., Zhou, L. H., Li, L., Zhang, Z. Y. and Huang, L. S. 2012. Mapping and fine mapping of quantitative trait loci for the number of vertebrae in a White Duroc $\times$ Chinese Erhualian intercross resource population. Anim Genet 43, 545-551.

30. SAS. 1997. SAS/STAT Software for PC. User's Guide, SAS Institue Inc., Cary, NC, USA.

31. Sato, S., Oyamada, Y., Atsuji, K., Nade, T., Sato, S., Kobayashi, E., Mitsuhashi, T., Nirasawa, K., Komatsuda, A., Saito, Y., Terai, S., Hayashi, T. and Sugimoto, Y. 2003. Quantitative trait loci analysis for growth and carcass traits in a Meishan $x$ Duroc $\mathrm{F}_{2}$ resource population. J Anim Sci 81, 2938-2949.

32. Soma, Y., Uemoto, Y., Sato, S., Shibata, T., Kadowaki, H., Kobayashi, E. and Suzuki, K. 2011. Genome-wide mapping and identification of new quantitative trait loci affecting meat production, meat quality, and carcass traits within a Duroc purebred population. J Anim Sci 89, 601-608.

33. Stewart, T. S. and Schinckel, A. P. 1989. Genetic parameters for swine growth and carcass traits. In: Young, L. D. (ed.), Genetics of Swine, pp. 77-79. USDA-ARS, Nebraska.

34. Uemoto, Y., Nagamine, Y., Kobayashi, E., Sato, S., Tayama, T., Suda, Y., Shibata, T. and Suzuki, K. 2008. Quantitative ttrait loci analysis on Sus scrofa chromosome 7 for meat production, meat quality, and carcass traits within a Duroc purebred population. J Anim Sci 86, 2833-2839.

35. Wada, Y., Akita, T., Awata, T., Furukawa, T., Sugai, N., Inage, Y., Ishii, K., Ito, Y., Kobayashi, E., Kusumoto, H., Matsumoto, T., Mikawa, S., Miyake, M., Murase, A., 
Shimanuki, S., Sugiyama, T., Uchida, Y., Yanai, S. and Yasue, H. 2000. Quantitative trait loci (QTL) analysis in a Meishan x Göttingen cross population. Anim Genet 31, 376-384.

36. Yoo, C. K., Cho, I. C., Lee, J. B., Jung, E. J., Lim, H. T., Lee, S. S., Ko, M. S., Kang, T. Hwang, J. H., Park, Y. S. and Park, H. B. 2012a. QTL analysis of clinical-chemical traits in an
$\mathrm{F}_{2}$ intercross between Landrace and Korean native pigs. Physiol Genomics 44, 657-668.

37. Yoo, C. K., Lim, H. T., Han, S. H., Lee, S. S., Ko, M. S., Kang, T., Lee, J. H., Park, H. B. and Cho, I. C. 2012b. QTL analysis of back fat thickness and carcass $\mathrm{pH}$ in an $\mathrm{F}_{2}$ intercross between Landrace and Korean native pigs. Mol Biol Rep 39, 8327-8333.

초록 : 제주재래흑돼지와 Landrace, 교배집단 $\mathrm{F}_{2}$ 에서 척추의 수적 변이와 도체형질의 상관관계

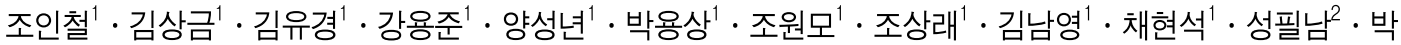
범영 $\cdot$ 이준헌 ${ }^{3} \cdot$ 이재봉 ${ }^{4} \cdot$ 유채경 ${ }^{4} \cdot$ 한상현 $^{5} \star \cdot$ 고문석 ${ }^{1} \star$

$\left({ }^{1}\right.$ 국립축산과학원 난지축산시험장, ${ }^{2}$ 국립축산과학원 축산물이용과, ${ }^{3}$ 충남대학교 축산학과, ${ }^{4}$ 경상대학교 응용 생명과학부, ${ }^{5}$ 제주대학교 교육과학연구소)

포유류 중 돼지의 척추 중 요추, 흥추의 수는 고정되지 않은 형 질로 개체간의 차이를 나타내는 것으로 알려져 있다. 본 연구는 제주재래흑돼지와 Landrace, 두 품종 간 $\mathrm{F}_{2}$ 교배집단에서 경추 수, 흥추 수, 요추 수, 척추 수 등 체형관련 형질과 도체형질의 상관관계를 살펴보기 위해 수행되었다. 세 축군 모두 경추 수의 변이는 나타나지 않았으나, 흥추 수, 요추 수, 척추 수는 상이한 양상을 보였다. 도체형질의 성적과 요추 수만이 세 축군들 사이에 서 통계적인 유의성을 나타내지 않았고( $p>0.05)$, 도체중, 육색, 근내지방도, 등심단면적, 등지방두께, 도체장, 흉추 수, 척추 수 등은 통계적인 유의성을 나타내었다( $p<0.05)$. 제주재래흑돼지는 흥추 수 14-16 개, 요추 수 5-6 개, 척추 수 27-29 개의 범위, Landrace는 흥추 수 15-16 개, 요추 수 5-7 개, 전체 척추 수 28-29 개, $\mathrm{F}_{2}$ 교배집단은 흥추 수 14-17, 요추 수 5-7 개, 전체 척추 수 27-30 개로 확인되었다. $\mathrm{F}_{2}$ 교배집단에서 흥추 수와 척추 수의 증가는 도체중, 도체장, 등지방두께의 평균이 유의적으로 다른 양상을 보인다( $p<0.05)$. 또한 척추 수의 증가는 요추 수의 증가보다 흥추 수의 증가에 더 많은 영향을 받는 것으로 나타났다. 흥추 수 및 척추 수의 증가가 등지방두께를 점점 두껍게 만들기는 하지만, 도체중과 도체장 등 경제성을 결정하는 핵심적인 도체형질을 향상시킨다는 점은 추후 제주재래흑돼지나 Landrace 품종을 활용한 양돈산업에서 체형개선을 통한 생산성 증가를 유발할 수 있는 좋은 전략이 될 것으로 판단된다. 